\title{
Analysis of Wear Particles Morphology of Machine Parts Based on Aluminium
}

\author{
Zdeněk Aleš ${ }^{1}$, Martin Pexa ${ }^{1}$, Jindřich Pavlů${ }^{1}$, Marián Kučera ${ }^{2}$, Jakub Čedík ${ }^{1}$ \\ ${ }^{1}$ Faculty of Engineering, Czech University of Life Sciences Prague, Department for Quality and Dependability of Ma- \\ chines, Kamýcká 129, 16521 Prague 6 - Suchdol, Czech Republic, E-mail: ales@tf.czu.cz, pexa@tf.czu.cz, \\ pavluj@tf.czu.cz, cedik.jakub@seznam.cz \\ ${ }^{2}$ Faculty of Environmental and Manufacturing Technology, Technical University in Zvolen, Department of Mechanics, \\ Mechanical Engineering and Design, Študentská 26, 96053 Zvolen, Slovakia, E-mail: kucera@tuzvo.sk
}

Failures of machines are caused by variety of external and internal effects and process that cause ultimately interruption of operation. These factors have resulted in changes of properties of machines parts and these changes are the first causes of technical failures. Wear is one of the major factors that contribute to the creation of failures and with this is connected generation of wear particles. Wear particles come into oil in lubrication system, where they cause contamination and degradation of lubricating properties and consequently it may result in major failure of machines. Among these contaminants are included mainly adhesive, abrasive and fatigue particles wear. The paper describes number and morphology of wear particles generated during modified Reichert test (friction pair steel and aluminium alloy) analysed by LasetNet Fines device. Experiment also compared capability of lubrication of four different engine oils exposed to various weight load.

Keywords: Wear particles, Reichert test, Particle morphology

\section{Acknowledgement}

Paper was created with the grant support - CZU CIGA 2015 - 20153001 - Use of butanol in internal combustion engines.

\section{References}

[1] ALES, Z., PEXA, M., (2010). Diagnostika maziv s využitím laserového analyzátoru LASERNET FINES®-C, Časopis - Strojírenská technologie, Ročník XIV, zvláštní vydání, Univerzita Jana Evangelisty Purkyně, FVTM, Ústí nad Labem, s. 8-11. ISSN 1211-4162

[2] CARROL R.I., BEYNON J.H. (2007). Rolling contact fatigue of white etching layer. Part 2. Numerical results, Wear, 262 (9-10), pp. 1267-1273. ISSN 0043-1648

[3] DOBRANSKY, J., KREVEL, R., (2010). Analýza kvality použitého oleja a meranie vibraci hrotového sústruhu SV 18RA, Časopis - Strojírenská technologie, Ročník XIV, zvláštní vydání, Univerzita Jana Evangelisty Purkyně, FVTM, Ústí nad Labem, s. 33-36. ISSN 1211-4162

[4] HERMANEK, P., MASEK, J., KRAL, J., (2010). Hydraulické kapaliny v letectví a jejich diagnostika, Časopis Strojírenská technologie, Ročník XIV, zvláštní vydání, Univerzita Jana Evangelisty Purkyně, FVTM, Ústí nad Labem, s. 70-73. ISSN 1211-4162

[5] HRABE, P., MÜLLER, M. (2013). Research of overlays influence on ploughshare lifetime. Research in Agricultural Engineering (Zemédělská technika), roč. 59, č. 4, s. 147-152. ISSN: 1212-9151.

[6] MÜLLER, M., HRABE, P. (2013) Overlay materials used for increasing lifetime of machine parts working under conditions of intensive abrasion. Research in Agricultural Engineering (Zemédělská technika), roč. 59, č. 1, s. 1622. ISSN: $1212-9151$.

[7] MÜller, M., LEBEDEV, A., SVOBOdOVA, J., NÁPRSTKOVA, N., LEBEDEV, P. (2014). Abrasive-free ultrasonic finishing of metals. Manufacturing Technology, roč. 14, č. 3, s. 366-370. ISSN: 1213-2489.

[8] MÜLlER, M., VALASEK, P. (2012). Abrasive wear effect on Polyethylene, Polyamide 6 and polymeric particle composites. Manufacturing Technology, Vol. 12, No. 12, pp. 55-59.

[9] POSTA, J. (2006). Provozuschopnost strojů. Česká zemědělská univerzita v Praze, 2. Vydání, Praha, ISBN 80213-0966-0

[10] WANG J., XING J., CAO L., Su W., GAO Y. (2010). Dry sliding wear behavior of Fe3Al alloys prepared by mechanical alloying and plasma activated sintering, Wear, 268 (2-3), pp. 473-480. ISSN 0043-1648 